\title{
Communication
}

[Comunicação]

\section{Efficacy of piperine in reducing the effects of aflatoxin intoxication in broiler chickens: a preliminary report}

\author{
[Eficácia da piperina na redução dos efeitos da intoxicação de frangos de corte \\ com aflatoxina: estudo preliminar] \\ V.S. Cardoso ${ }^{1}$, I.S. Castro ${ }^{1}$, C.A.R. Lima $^{2}$, M.E.F. Lima ${ }^{3}$, L.E.G. Dorneles ${ }^{3}$, \\ G.M. Direito ${ }^{1}$, M.G.M. Danelli ${ }^{1}$ * \\ ${ }^{1}$ Instituto de Veterinária - UFRRJ \\ ${ }^{2}$ Instituto de Zootecnia - UFRRJ \\ ${ }^{3}$ Instituto de Ciências Exatas - UFRRJ \\ 23890-000 - Seropédica, RJ
}

Aspergillus flavus and A. parasiticus are filamentous fungi that infect oil seeds and tree nuts and contaminate these commodities with toxic secondary metabolites, such as aflatoxin. These mycotoxins are hepatotoxic and carcinogenic (Groopman and Kensler, 2005). Besides, aflatoxin has immunosuppressive properties, increasing susceptibility of infections and decreasing protection conferred by vaccination (Venturini et al., 1996).

The occurrence of aflatoxin in poultry and animal foodstuffs is quite common in many countries and causes great economic losses (Charmley et al., 1995). Since the discovery of aflatoxin in the 1960s, researchers have screened numerous natural products and synthetic compounds that are able to inhibit the biosynthesis of aflatoxin products by fungi. Most of these inhibitors (phenylpropanoids, terpenoids, and alkaloids) can act by altering the physiological environment or other signaling inputs perceived by the fungus, interfering with regulatory networks of signal transduction and gene expression in the aflatoxin biosynthesis, or by blocking the enzymatic activity of a biosynthetic enzyme (Holmes et al., 2008). However, most of these compounds are potentially unsafe because of the formation of toxic residues or alteration of nutrient content, flavor, and odor of the product. Therefore, new practical and effective methods of eliminating aflatoxicosis are being sought. Valdivia et al.
(2001) studied the efficacy of N-acetylcysteine (NAC), an antidote against several toxic agents, to reduce aflatoxin B1 effects in broiler chickens. They observed that NAC was able to provide protection against liver and renal damage induced by aflatoxin $\mathrm{B}_{1}$.

The black pepper (Piper nigrum) spice can inhibit the aflatoxin production by $A$. flavus (Mabrouk and El-Shayeb, 1992). Piperine is an amide constituent of many pepper species, which inhibit the aflatoxin production $\left(\mathrm{IC}_{50}<35 \mu \mathrm{M}\right)$ by A. parasiticus, with a moderate reduction in its growth (Madhyastha and Bhat, 1984). The action mode of piperine against aflatoxin production by the fungi is not known yet. Piperine can also interfere on the action mechanism of aflatoxins in mammalian cells. Reen et al. (1997) showed the chemopreventive efficacy of piperine in procarcinogens, activated by in vitro $\mathrm{P}-450$ cytochromes. In addition to these effects, piperine has been reported to display depressant, antipyretic, analgesic, and anti-inflammatory activities in the central nervous system (Parmar et al., 1997), as well as to inhibit the in vitro and in vivo production of nitric oxide, tumor necrosis factor- $\alpha$, and lung metastasis (Pradeep and Kuttan, 1999).

The aim of this work was to analyze whether oral supplementation with piperine can prevent the appearance of negative effects during subacute aflatoxin intoxication in broiler chickens.

Recebido em 16 de março de 2010

Aceito em 10 de fevereiro de 2011

Autor para correspondência (corresponding author)

E-mail: danelli@ufrrj.br 
Piperine was obtained according to Ikan (1991), in $5-7 \%$ yield and $98 \%$ purity, determined by gas chromatography-mass spectrometry (GC-MS). It was dissolved in 1.0mL DMSO/ethanol 10\% right before use. Aflatoxins were obtained from cultures of A. parasiticus CMDB 0460, NRLL 2999 strain in YES culture media (Micromed) at $37^{\circ} \mathrm{C}$, and its quantification was performed by high-performance liquid chromatography (HPLC), according to Direito (1989). The aflatoxin solution (containing $62.9 \%$ of aflatoxin B1 and $37.1 \%$ of aflatoxin G1) was dissolved in maize oil and vigorously homogenized in an ultrasound bath.

A total of 48 seven-day-old male Cobb broiler chicks were randomly distributed into four experimental groups $(\mathrm{n}=12)$ : group 1 (PBS $0.01 \mathrm{M}, \mathrm{pH} 7.2$ ); group 2 (2.25mg of piperine $\mathrm{kg}^{-}$ $\left.{ }^{1}\right)$; group 3 (2.0mg of aflatoxin $\left.\mathrm{kg}^{-1}\right)$, and group 4 $\left(2.25 \mathrm{mg}\right.$ of piperine $\mathrm{kg}^{-1}$ and $2.0 \mathrm{mg}$ of aflatoxin $\mathrm{kg}^{-1}$ afterwards). PBS, piperine, and aflatoxin were mixed $(\mathrm{v} / \mathrm{v})$ with maize oil and the mixture was orally administrated to all chicks during consecutive 14 days, with the exception of group 4 , chicks which began the piperine treatment one day before the aflatoxin administration. The chicks were kept in a standard environmental condition under natural light and were given a balanced feed, mycotoxin-free (HPLC analysis), and water ad libitum.

At end of the experiment, the broilers were weighed and slaughtered, in compliance with the rules established by the Brazilian Department of Agriculture Livestock and Supply (http:/extranet.agricultura.gov.br/sislegisconsulta/consultarlegislacao.do).
The evaluated parameters are shown in tables and the results were expressed as mean \pm SD. The significance mean of different parameters between groups was analyzed using the one-way analysis of variance, after ascertaining the homogeneity of variance between treatments. A difference was considered statistically significant when $\mathrm{P}<0.05$.

According to this study, oral administration of aflatoxin during the experimental period did not promote death or changes in the clinical condition of chickens; however, there was a significant decrease in the average body weight gain. The anatomopathological evaluation of the liver, performed at the time of slaughter, showed no changes in its shape, texture, nor color. Nevertheless, there was a significant increase in the relative liver weight and injury levels, which were characteristic of aflatoxin intoxication observed at the histopathological examination (Table 1). Regarding hematological parameters (Table 2), aflatoxin-intoxicated broilers exhibited modification of hematological profiles, characterized by anemia and leukopenia $(\mathrm{P}<0.001)$. On the other hand, the oral administration of piperine in broilers intoxicated by aflatoxin improved the relative weight of liver, weight gain, and hematological parameters (Table 2), and also prevented the development of liver injury (Table 1). Aflatoxin-intoxicated broilers that received piperine showed an infiltration of mononuclear cells varying from mild to moderate, similar to the group that only received piperine. It is important to observe that animals that only received piperine were able to increase the number of leukocytes (Table 2).

Table 1. Histopathological lesions observed in the liver of broiler chickens

\begin{tabular}{lcccc}
\multicolumn{2}{c}{ Histopathological lesions of the liver } & \multicolumn{4}{c}{ Treatments $^{2}$} \\
\cline { 2 - 5 } & Control & Piperine $^{1}$ & Aflatoxin $^{2}$ & $\mathrm{P}^{2} \mathrm{~A}^{3}$ \\
\hline Mitosis & - & - & - & - \\
Apoptosis & - & - & ++ & - \\
Megalocytosis & $(+)$ & + & ++ & - \\
Mononuclear cell infiltrate regions & - & - & ++ & $+(+)$ \\
Congestion of epithelial cells of the bile duct & - & - & ++ & - \\
Necrosis of biliary ducts & & - & ++ & - \\
Vacuolar degeneration & - & - & ++ & - \\
Edema & - & - & + & - \\
Diffuse vacuolation of hepatocytes & - & - & +
\end{tabular}

Lesions observed in the majority of the animals: no lesion [-], discreet $[(+)]$, light $[+]$, light to moderate $[+(+)]$, moderate $[++]$, marked [+++].

${ }^{1}$ Piperine (2.25 $\mathrm{mg} \mathrm{kg}^{-1}$ of piperine); ${ }^{2}$ Aflatoxins (2.0 $\mathrm{mg} \mathrm{kg}^{-1}$ of aflatoxins); ${ }^{3}$ Piperine associated to aflatoxins (225mg $\mathrm{kg}^{-1}$ of piperine and $2.0 \mathrm{mg} \mathrm{kg}^{-1}$ of aflatoxins). 
Table 2. Influence of piperine and aflatoxin on the average weight gain, average liver weight, and on the hematological parameters of broiler chickens

\begin{tabular}{|c|c|c|c|c|}
\hline \multirow[b]{2}{*}{ Parameters } & \multicolumn{4}{|c|}{ Piperine (mg kg ${ }^{-1}$ ) } \\
\hline & Control & Piperine $^{1}(\mathrm{P})$ & Aflatoxin $^{2}(\mathrm{~A})$ & $P+A^{3}$ \\
\hline Viability (\%) & 100 & 100 & 100 & 100 \\
\hline Weight gain (g) & $942.30 \mathrm{a} \pm 78.44$ & $935.70 a \pm 36.39$ & $881.00 \mathrm{~b} \pm 62.40$ & $904.00 \mathrm{ab} \pm 48.85$ \\
\hline RWL (mg $100 g^{-1}$ ) & $2.39 \mathrm{ab} \pm 0.06$ & $2.32 \mathrm{a} \pm 0.05$ & $2.65 c \pm 0.12$ & $2.29 \mathrm{ab} \pm 0.14$ \\
\hline $\operatorname{RBC}\left(\times 10^{6-} \mu L^{-1}\right)$ & $2.22 \mathrm{a} \pm 0.20$ & $2.49 b \pm 0.10$ & $1.90 c \pm 0.12$ & $2.19 a \pm 0.14$ \\
\hline Hct $(\%)$ & $31.53 \mathrm{a} \pm 2.94$ & $30.67 a \pm 1.45$ & $28.53 b \pm 1.88$ & $29.13 b \pm 1.25$ \\
\hline $\mathrm{Hb}\left(\mathrm{g} \mathrm{dL}^{-1}\right)$ & $8.05 a \pm 0.79$ & $7.61 \mathrm{ab} \pm 0.43$ & $7.41 \mathrm{~b} \pm 0.48$ & $7.84 \mathrm{ab} \pm 0.29$ \\
\hline MCV (fL) & $142.50 \mathrm{a} \pm 11.69$ & $123.40 \mathrm{~b} \pm 11.10$ & $150.30 c \pm 5.95$ & $133.30 \mathrm{~d} \pm 9.33$ \\
\hline $\mathrm{MCHC}\left(\mathrm{gm} \mathrm{dL}^{-1}\right)$ & $25.08 \mathrm{ab} \pm 1.22$ & $24.63 a \pm 1.98$ & $26.19 b c \pm 1.66$ & $26.74 \mathrm{c} \pm 1.05$ \\
\hline PPT $\left(\mathrm{g} \mathrm{dL}^{-1}\right)$ & $3.35 a \pm 0.24$ & $3.19 \mathrm{~b} \pm 0.16$ & $2.46 c \pm 0.09$ & $2.67 \mathrm{~d} \pm 0.76$ \\
\hline $\mathrm{WBC}\left(\mathrm{x} 10^{3} \mu \mathrm{L}^{-1}\right)$ & $30.07 a \pm 4.07$ & $33.73 b \pm 3.35$ & $19.00 c \pm 2.56$ & $26.60 \mathrm{~d} \pm 4.10$ \\
\hline
\end{tabular}

Data are expressed by the group \pm standard deviation. Statistical analysis made by analysis of variance.

${ }^{1}$ Piperine (2.25 $\mathrm{mg} \mathrm{kg}^{-1}$ of piperine); ${ }^{2}$ Aflatoxin (2.0 $\mathrm{mg} \mathrm{kg}^{-1}$ of aflatoxin); ${ }^{3}$ Piperine associated to aflatoxin (2.25mg $\mathrm{kg}^{-1}$ of piperine and $2.0 \mathrm{mg} \mathrm{kg}^{-1}$ of aflatoxin).

Means followed by distinct letters in the same row are different $(\mathrm{P}<0.05)$.

RWL: relative liver weight; RBC: red blood cell; Hct: hematocrit; Hb: hemoglobin; MCV: mean corpuscular volume; MCHC: mean corpuscular hemoglobin; PPT: total plasmatic protein; WBC: white blood cell.

These results suggested that piperine intake decreased the severity of the toxic effects of aflatoxins in broiler chickens, preventing the development of liver injury and the adverse effects on hematological parameters, which are characteristic of aflatoxicosis. These preliminary data suggest that piperine might be used to prevent the effects of aflatoxin ingestion.

Keywords: broiler chickens, intoxication, mycotoxin, aflatoxin, piperine

\section{RESUMO}

Aflatoxina é uma micotoxina que promove importantes efeitos tóxicos na saúde humana e animal, mesmo quando consumida em baixas doses. A administração oral de piperina (2,25mg $\mathrm{Kg}-1)$ em frangos de corte, por 14 dias consecutivos, aparentemente interferiu na toxidez da aflatoxina, diminuindo os danos hepáticos e seus efeitos adversos sobre os parâmetros hematológicos característicos da aflatoxicose. Esses dados preliminares sugerem que a piperina poderia ser usada na prevenção dos efeitos tóxicos originados pela ingestão de aflatoxina.

Palavras-chave: frango de corte, intoxicação, micotoxina, aflatoxina, piperina

\section{ACKNOWLEDGEMENTS}

This study was supported by grants from $\mathrm{CNPq}$ (470924/2007) and CAPES.

\section{REFERENCES}

CHARMLEY, L.; TRENHOLM, H.; PRELUSKY, D. et al. Economic losses and decontamination. Nat. Toxins, v.3, p.199-203, 1995.
DIREITO, G.M. Desenvolvimento da fase móvel para separação de aflatoxinas por cromatografia líquida de alta eficiência utilizando fase normal em sistemas de compressão radial. 1989. 67f. Dissertação (Mestrado) - Universidade Federal Rural do Rio de Janeiro, Seropédica, RJ.

GROOPMAN, J.D.; KENSLER T.W. Role of metabolism and viruses in aflatoxin-induced liver cancer. Toxicol. Appl. Pharmacol., v.206, p.131-137, 2005. 
HOLMES, R.A.; BOSTON, R.S.; PAYNE, G.A. Diverse inhibitors of aflatoxin biosynthesis. Appl. Microbiol. Biotechnol., v.4, p.559-572, 2008.

IKAN, R. In natural products. A laboratory guide 2.ed. New York: Academic, 1991. p.233238.

MABROUK, S.S.; EL-SHAYEB, N.M.A. Inhibition of aflatoxin production in Aspergillus flavus by natural coumarins and chromones. World J. Microbiol. Biotechnol., v.8, p.7-84, 1992.

MADHYASTHA, M.S.; BHAT, R.V. Aspergillus parasiticus growth and aflatoxin production on black and white pepper and the inhibitory action of their chemical constituents. Appl. Environ. Microbiol., v.48, p.376-379, 1984.

PARMAR, V.S.; JAIN, S.C.; BISHT, K.S. et al. Phytochemistry of the genus Piper. Phytochemistry, v.46, p.597-673, 1997.
PRADEEP. C.R.; KUTTAN, G. Effect of piperine on the production of nitric oxide and TNF-alfa in vitro as well as in vivo. Immunopharmacol. Immunotoxicol., v.25, p.337346, 1999.

REEN, K.R.; WIEBEL, J.F.; SINGH, J. Piperine inhibits aflatoxin $\mathrm{B}_{1}$-induced cytotoxicity and and genotoxicity in V79 Chinese hamster cells genetically engineered to express rat cytochrome P4502B1. J. Ethnopharmacol., v.58, p.165-173, 1997.

VALDIVIA, A.G.; MARTÍNEZ, A.; DAMIÁN, F.J. et al. Efficacy of $\mathrm{N}$-acetylcysteine to reduce the effects of aflatoxin B1 intoxication in broiler chickens. Poult. Sci., v.80, p.727-734, 2001.

VENTURINI, M.C.; QUIROGA, M.A.; RISSO, M.A. et al. Mycotoxin T-2 and aflatoxin B1 as immunosuppressors in mice chronically infected with Toxoplasma gondii. J. Comp. Pathol., v.115, p.229-237, 1996. 